\title{
Pengaruh Pemberian Silase Campuran Indigofera sp. dan Rumput Gajah Pada Berbagai Rasio terhadap Kecernaan Serat Kasar dan BETN Pada Domba Garut Jantan
}

\author{
A. S. Wijaya ${ }^{1 a}$, T. Dhalika ${ }^{2}$, dan S. Nurachma ${ }^{2}$ \\ ${ }^{I}$ Alumni Fakultas Peternakan Universitas Padjadjaran \\ ${ }^{2}$ Staf Pengajar Fakultas Peternakan Universitas Padjadjaran \\ aemail: annisasavitriwijaya@gmail.com
}

\begin{abstract}
Abstrak
Penelitian ini bertujuan untuk mengetahui rasio terbaik Indigofera $s p$. dan Rumput Gajah dalam bentuk silase yang menghasilkan kecernaan serat kasar dan BETN tertinggi pada Domba Garut jantan. Penelitian ini menggunakan metode eksperimental dengan Rancangan Acak Lengkap (RAL) dan lima perlakuan. Ransum perlakuan terdiri atas silase campuran Indigofera sp. dan Rumput Gajah dengan berbagai rasio yaitu T1 (0\% dan 100\%), T2 (10\% dan 90\%), T3 (20\% dan 80\%), T4 (30\% dan 70\%), dan T5 (40\% dan 60\%) serta pada tiap perlakuan ditambahkan Konsentrat dalam jumlah yang sama. Setiap perlakuan diulang sebanyak lima kali. Data hasil penelitian diolah menggunakan analisis ragam dan dilanjutkan dengan Uji Jarak Berganda Duncan. Hasil analisis statistik menunjukkan bahwa pemberian pemberian silase campuran Indigofera $s p$. dan Rumput Gajah memberikan pengaruh terhadap kecernaan serat kasar, namun tidak memberikan pengaruh terhadap kecernaan BETN pada Domba Garut jantan. Silase campuran Indigofera sp. 20\% dan Rumput Gajah 80\% menghasilkan nilai kecernaan serat kasar tertinggi.

Kata kunci: Indigofera sp., Rumput Gajah, Kecernaan Serat Kasar dan BETN, Domba Garut jantan.

\section{The Effect of Mixed Silage Indigofera sp. and Elephant Grass in Various Ratio on Crude Fiber adn Nitrogen Free Extract (NFE) Digestibility in Garut Male Sheep}

\footnotetext{
Abstract

The research aims to determine the optimum ratio of mixed silage Indigofera sp. and Elephant Grass which produces the highest crude fiber and nitrogent free extract (NFE) digestibility in Garut male sheep. Experimental method was used with a completely randomized design for five treatment based on various ratio of Indigofera sp. and Elephant Grass i.e. T1 (0\% and 100\%), T2 (10\% and 90\%), T3 (20\% and $80 \%)$, T4 (30\% and $70 \%)$, and T5 (40\% and $60 \%)$ also in every treatment added same amount of Concentrate. Each treatment was five times repeated. The data analyzed with ANOVA test and Duncan's multiple range test. The result of statistical analysis showed that the inclution of mixed silage Indigofera sp. and Elephant Grass was significant on crude fiber digestibility, but was not significant on nitrogent free extract (NFE) digestibility. The mixed silage Indigofera $s p .20 \%$ and Elephant Grass $80 \%$ showed the highest level of crude fiber digestibility.

Keywords: Indigofera sp., Elephant Grass, Crude Fiber and Nitrogen Free Extract (NFE) Digestibility, Garut Male Sheep.

\section{Pendahuluan}

Pakan merupakan salah satu aspek penting dalam pemeliharaan ternak. Menurut beberapa peneliti terdahulu pakan mengambil

porsi biaya produksi sampai $70 \%$ dan sangat mempengaruhi pemeliharaan suatu komoditas ternak, baik dalam segi kualitas maupun kuantitas yang dihasilkan ternak tersebut.
} 
Hijauan merupakan bahan pakan utama bagi ternak ruminansia termasuk domba dan dapat dikonsumsi dalam bentuk segar maupun yang sudah dilakukan pengolahan terlebih dahulu baik pengolahan secara fisik, kimia, maupun biologi. Pemenuhan kebutuhan hijauan tersebut tidak hanya dapat dipenuhi rumput namun dapat juga memanfaatkan legum yang pada dasarnya memiliki nilai nutrisi yang tinggi.

Penyediaan pakan ternak secara berkelanjutan merupakan hal yang sangat penting untuk keberlangsungan hidup ternak dan harus dapat tersedia sepanjang tahun, namun sering terkendala pada lahan untuk penanaman hijauan yang terbatas dan pengaruh musim. Pada musim hujan hijauan melimpah, sementara pada musim kemarau hijauan mengalami kekeringan. Salah satu cara untuk mengatasi permasalahan tersebut adalah dengan pengolahan hijauan melalui pembuatan silase.

Indigofera sp. merupakan tanaman legum yang sangat potensial sebagai pakan sumber protein pada domba yang memiliki daya adaptasi tinggi terhadap lingkungan. Sementara Rumput Gajah merupakan salah satu jenis rumput yang sudah dikenal masyarakat dan lazim digunakan sebagai pakan ternak karena produktivitas tanaman yang tinggi.

Pembuatan silase campuran Indigofera $s p$. dan Rumput Gajah diharapkan dapat selalu tersedia dengan daya simpan lama dan memiliki palatabilitas yang baik sehingga konsumsi serta kebutuhan nutrisi dari ternak domba khususnya dalam pemenuhan karbohidrat melalui konsumsi serat kasar dan BETN dapat terpenuhi.

Domba Garut merupakan hewan ruminansia kecil dan salah satu plasma nutfah yang patut untuk dibudidayakan baik sebagai tipe ternak pedaging maupun untuk seni ketangkasan. Domba Garut membutuhkan hijauan pakan untuk memenuhi kebutuhan akan karbohidrat yang diperoleh melalui konsumsi serat kasar dan BETN (Bahan Ekstrak Tanpa Nitrogen) yang berfungsi sebagai sumber energi pada ternak.

Berdasarkan uraian tersebut, penulis tertarik melakukan penelitian mengenai pengaruh pemberian silase berbasis campuran Indigofera $s p$. dan Rumput Gajah pada berbagai rasio terhadap kecernaan serat kasar dan BETN pada Domba Garut jantan.

\section{Materi dan Metode Bahan Penelitian}

Bahan pakan penyusun ransum penelitian terdiri atas Indigofera $s p$. dalam bentuk kering, Rumput Gajah, dan Konsentrat.

\section{Objek Penelitian}

Penelitian ini menggunakan Domba Garut jantan berumur \pm 10 bulan sebanyak 25 ekor dengan rata-rata bobot badan awal 23,76 $\pm 2,08 \mathrm{~kg}$ dengan koefisien variasi sebesar $8,73 \%$.

\section{Metode Penelitian}

\section{Tahap Pendahuluan}

1) Pembuatan Silase

Silase campuran Indigofera $s p$. dan Rumput Gajah dibuat dengan menggunakan Indigofera $s p$. dalam bentuk kering serta Rumput Gajah yang telah dilayukan terlebih dahulu. Pembuatan silase dihitung berdasarkan asfeed. Silase dibuat dengan menambahkan starter yaitu dedak padi aromatik yang dibuat dari dedak padi, molases, dan probiotik yang dicampurkan hingga homogen. Penambahan starter dedak padi aromatik sebesar $1 \%$ dari total berat bahan yang akan dibuat silase.

Indigofera $s p$. dalam bentuk kering, Rumput Gajah, dan dedak padi aromatik dihomogenkan lalu dimasukkan sedikit demi sedikit kedalam tong hingga padat dan kondisi anaerob. Pematangan silase dilakukan selama 10 hari. Pembuatan silase dilakukan di Laboratorium Ternak Potong Fakultas Peternakan Universitas Padjadjaran.

2) Persiapan Kandang dan Persiapan Ternak

Persiapan kandang meliputi pembuatan kandang dan penentuan peletakkan ternak dan perlakuan. Persiapan ternak meliputi pembelian ternak yaitu Domba Garut jantan berumur \pm 10 bulan yang berasal dari daerah Majalaya, Jawa Barat. Dilanjutkan dengan adaptasi ternak terhadap lingkungan dan pakan selama 42 hari.

\section{Tahap Perlakuan}

Pemeliharaan tenak dilakukan selama 60 hari meliputi pemberian pakan, penimbangan sisa pakan, penimbangan bobot badan. Pemberian pakan dilakukan tiga kali dalam satu hari, yaitu pemberian pakan silase pada 
pagi hari pukul 07.00 WIB sebanyak 2000 gram/ekor, pemberian konsentrat sebanyak 500 gram pada siang hari pukul 12.00 WIB, dan pemberian pakan silase kembali pada sore hari pada pukul 17.00 WIB sebanyak 2000 gram/ekor sementara untuk pemberian air minum dilakukan ad libitum. Pemberian silase dilakukan berdasarkan kebutuhan bahan kering dengan pemberian asfeed.

\section{Tahap Pengumpulan Data}

Pengumpulan data meliputi data konsumsi ransum dan data feses yang dilakukan selama 5 hari. Prosedur pengumpulan data yaitu menghitung konsumsi ransum selama 24 jam, menghitung eksresi feses domba selama 24 jam, Mengambil sampel feses sebanyak 100 gram lalu menyemprot feses dengan larutan asam borak $\left(\mathrm{H}_{3} \mathrm{BO}_{3}\right)$ 5\% kemudian menjemur feses hingga kering.

Selanjutnya menimbang kembali berat feses yang telah kering dan memasukkan feses kedalam plastik yang telah diberi label masing-masing perlakuan, lalu memisahkan feses dari rambut domba yang menempel, dan terakhir melakukan analisis proksimat di laboratorium untuk menentukan nilai kecernaan.

\section{Peubah yang Diamati}

\section{Kecernaan Serat Kasar}

Perhitungan kecernaan serat kasar diperoleh berdasarkan rumus Tillman (1991) sebagai berikut :

Kecernaan $(\%)=\frac{\text { KSK }- \text { FSK }}{\mathrm{KSK}} \times 100 \%$

Keterangan :

KSK $=$ Jumlah konsumsi serat kasar

FSK $=$ Jumlah serat kasar dalam feses

\section{Kecernaan BETN}

Perhitungan kecernaan BETN diperoleh berdasarkan rumus Tillman (1991) sebagai berikut :

Kecernaan $(\%)=\frac{\text { KBETN }- \text { FBETN }}{\text { KBETN }} \times 100 \%$

Keterangan :

KBETN $=$ Jumlah konsumsi BETN

FBETN $=$ Jumlah BETN dalam feses

\section{Rancangan Percobaan}

Penelitian dilakukan dengan metode eksperimental menggunakan rancangan acak lengkap (RAL) yang terdiri dari 5 perlakuan dengan 5 pengulangan pada setiap perlakuan. Perlakuan yang diberikan adalah sebagai berikut dan pada tiap perlakuan diberikan Konsentrat dengan jumlah yang sama.

$\mathrm{T} 1$ : Silase Indigofera sp. . $\%$ + Rumput Gajah 100\% T2 : Silase Indigofera sp. 10\% + Rumput Gajah 90\%

T3 : Silase Indigofera sp. 20\% + Rumput Gajah 80\%

T4 : Silase Indigofera sp. 30\% + Rumput Gajah 70\%

T5 : Silase Indigofera sp. 40\% + Rumput Gajah 60\%

\section{Analisis Statistika}

Guna mengetahui pengaruh perlakuan terhadap peubah yang diamati dilakukan analisis ragam, sedangkan untuk mengetahui perbedaan antar perlakuan dilakukan Uji Jarak Berganda Duncan.

\section{Tata Letak Percobaan}

Penentuan tata letak percobaan dilakukan secara acak dengan cara pengundian. Pengundian dilakukan pada perlakuan (treatment) dan domba yang akan digunakan. Pengacakan (randomization) yaitu setiap unit percobaan diberi kesempatan yang sama untuk memperoleh perlakuan tertentu.

\section{Hasil dan Pembahasan}

\section{Kecernaan Serat Kasar}

Nilai kecernaan serat kasar dari silase campuran Indigofera $s p$. dan Rumput Gajah pada Domba Garut jantan disajikan pada Tabel 1.

Nilai kecernaan serat kasar yang diperoleh sesuai dengan pendapat Anggorodi (1990) bahwa kadar serat kasar yang dapat dicerna oleh ruminansia adalah $50-90 \%$.

Hasil analisis statistika menunjukkan bahwa pemberian silase campuran Indigofera $s p$. dan Rumput Gajah pada berbagai rasio memberikan pengaruh nyata $(\mathrm{P}<0,05)$ terhadap kecernaan serat kasar pada Domba Garut jantan. Perbedaan antar perlakuan diuji menggunakan Uji Jarak Berganda Duncan. 
Tabel 1. Nilai Kecernaan Serat Kasar

\begin{tabular}{|c|c|c|c|c|c|}
\hline \multirow{2}{*}{ Ulangan } & \multicolumn{5}{|c|}{ Perlakuan } \\
\hline & T1 & $\mathrm{T} 2$ & T3 & T4 & T5 \\
\hline & & &..$\%$ & & \\
\hline 1 & 64,66 & 71,17 & 79,18 & 56,46 & 61,54 \\
\hline 2 & 65,66 & 63,66 & 75,81 & 72,21 & 64,68 \\
\hline 3 & 71,14 & 81,85 & 71,59 & 67,04 & 62,53 \\
\hline 4 & 73,28 & 74,45 & 64,08 & 59,39 & 60,87 \\
\hline 5 & 76,57 & 71,24 & 73,32 & 61,16 & 51,11 \\
\hline Rataan & $70,26^{\text {bc }}$ & $72,42^{\mathrm{c}}$ & $72,80^{\mathrm{c}}$ & $63,25^{\mathrm{ab}}$ & $60,15^{\mathrm{a}}$ \\
\hline
\end{tabular}

Keterangan : Huruf yang berbeda menunjukkan hasil yang berbeda nyata $(\mathrm{P}<0,05)$.

Kecernaan serat kasar tertinggi diperoleh pada ransum perlakuan dengan kombinasi campuran silase Indigofera sp. 20\% dan Rumput Gajah $80 \%$ sebesar $72,80 \%$. Nilai kecernaan yang didapat dari penelitian ini lebih tinggi jika dibandingkan dengan hasil penelitian Tarigan dan Ginting (2011) yang menunjukkan nilai rataan kecernaan NDF dan ADF pada Kambing yang diberi ransum dengan kandungan Indigofera sp. 0\% - 45\% adalah sebesar 44,4\% - 52,1\% untuk kecernaan NDF, 43,7\% - 55,1\% untuk kecernaan ADF. Hal tersebut karena nilai kecernaan dipengaruhi oleh komposisi bahan makanan dan ransum serta faktor ternak. Tillman (1991) menyatakan bahwa faktor yang berpengaruh terhadap kecernaan antara lain adalah faktor hewan dan komposisi pakan.

Nilai kecernaan dari perlakuan yang diberikan mengalami peningkatan mulai dari ransum perlakuan $\mathrm{T} 1, \mathrm{~T} 2$, dan yang paling tinggi pada ransum perlakuan T3. Namun pada ransum perlakuan $\mathrm{T} 4$ dan $\mathrm{T} 5$ nilai kecernaan serat kasar menurun.

Hal ini diduga karena kandungan Indigofera $s p$. yang lebih tinggi dalam ransum percobaan yang berhubungan dengan kandungan karbohidrat struktural yaitu selulosa, hemiselulosa, NDF, ADF, serta lignin dalam Indigofera $s p$. tersebut, adanya zat anti nutrisi yang terkandung dalam Indigofera $s p$. yaitu tanin, serta konsumsi pakan dan kecepatan pengeluaran zat makanan dari saluran pencernaan.

Kandungan karbohidrat struktural yang tinggi pada Indigofera $s p$. dapat berdampak kepada penurunan konsumsi dan kecernaan pakan. Beberapa spesies Indigofera memiliki kandungan karbohidrat struktural NDF berkisar $30-44 \%$, ADF $23-33 \%$, hemiselulosa 5 - 10\%, selulosa 17 - 18\%, dan lignin 4 - 8\% (Ginting dkk., 2012).

Acid Detergent Fibre (ADF) dan

Neutral Detergent Fibre (NDF) merupakan fraksi dinding sel dengan nilai cerna rendah (Sudirman dkk., 2015). Lignin merupakan substansi kompleks yang tidak dapat dicerna. Hemiselulosa dan selulosa merupakan komponen dinding sel yang dapat dicerna oleh mikroba. Lebih tingginya fraksi dinding sel yang sulit dicerna maupun tidak dapat dicerna dapat mempengaruhi kecernaan serat kasar.

Faktor lain adalah adanya zat anti nutrisi pada Indigofera $s p$. yaitu tanin. Kandungan protein yang lebih tinggi dalam ransum perlakuan T4 dan T5 diduga menjadi salah satu penyebab nilai kecernaannya yang lebih rendah dibanding ransum perlakuan lain.

Protein umumnya berikatan dengan tanin dan ikatan tanin-protein yang kuat tersebut dapat menurunkan daya cerna zat makanan (Firdaus, 2010). Kandungan tanin yang meningkat seiring dengan meningkatnya jumlah Indigofera $s p$. dalam ransum dapat mempengaruhi nilai kecernaan serat kasar sehingga menjadi rendah.

Faktor lain yang diduga menjadi penyebab menurunnya kecernaan serat kasar pada ransum perlakuan $\mathrm{T} 4$ dan $\mathrm{T} 5$ adalah konsumsi pakan dan kecepatan pengeluaran zat makanan dari saluran pencernaan. Hal ini sesuai dengan pendapat Anggorodi (1990) bahwa laju perjalanan makanan melalui alat pencernaan juga merupakan faktor yang mempengaruhi nilai kecernaan.

Bila makanan yang dikonsumsi melewati saluran pencernaan terlalu cepat, maka penyerapan zat-zat makanan yang dilakukan oleh alat pencernaan tidak berjalan sempurna dan enzim pencernaan tidak memiliki waktu yang cukup untuk mencerna 
zat-zat makanan tersebut sehingga nilai kecernaan rendah (Anggorodi, 1990). Kandungan protein pada ransum perlakuan $\mathrm{T} 4$ dan T5 yang lebih tinggi dibandingkan perlakuan lainnya juga akan mempengaruhi pertumbuhan mikroorganisme yang akan meningkatkan laju degradasi pakan sehingga serat kasar yang terdapat dalam pakan tidak diserap secara sempurna sehingga nilai kecernaan menjadi rendah.

\section{Kecernaan BETN}

Nilai kecernaan BETN dari silase campuran Indigofera $s p$. dan Rumput Gajah pada Domba Garut jantan disajikan pada Tabel 2.

Nilai kecernaan BETN yang diperoleh sesuai dengan pendapat Parakkasi (1999) bahwa kadar BETN yang dapat dicerna oleh ruminansia adalah 39-94\%. Angka kecernaan BETN tertinggi yaitu $61,47 \%$ diperoleh pada ransum perlakuan dengan kombinasi campuran silase Indigofera sp. 20\% dan Rumput Gajah $80 \%$. Hasil analisis statistika menunjukkan bahwa pemberian silase campuran Indigofera $s p$. dan Rumput Gajah pada berbagai rasio tidak memberikan pengaruh nyata $(\mathrm{P}>0,05)$ terhadap kecernaan BETN pada Domba Garut jantan Menurut Anggorodi (1990), daya
cerna komponen BETN lebih tinggi
dibandingkan dengan daya cerna serat kasar. Fraksi BETN yang pada hakikatnya merupakan fraksi yang mudah dicerna menjadi salah satu faktor yang mempengaruhi daya cerna BETN yang lebih tinggi tersebut. BETN (Bahan Ekstrak Tanpa Nitrogen) merupakan fraksi karbohidrat yang lebih mudah dicerna karena mengandung mono-, di-, tri-, dan tetra- sakarida ditambah pati dan beberapa bahan yang termasuk hemiselulosa (Tillman, 1991).

Kecernaan BETN yang tidak berpengaruh nyata $(\mathrm{P}>0,05)$ tersebut dapat dipengaruhi kadar BETN yang terdapat dalam ransum perlakuan yang hampir sama jumlahnya (Tabel 4). Kandungan BETN pada ransum yang hampir sama pada tiap perlakuan tersebut menyebabkan mikroba pencerna BETN yang tersedia juga relatif sama. Budiman dkk. (2006) menyatakan bahwa meningkatnya energi mudah dicerna dan protein akan membantu peningkatan bakteri amilolitik. Dimana bakteri amilolitik tersebut adalah bakteri pencerna pati yang benyak terkandung didalam BETN. Sehingga keadaan tersebut menyebabkan nilai kecernaan yang didapatkan pada kelima perlakuan tidak berbeda nyata.

\section{Kesimpulan}

1. Pemberian silase campuran Indigofera sp. dan Rumput Gajah memberikan pengaruh terhadap kecernaan serat kasar, namun tidak memberikan pengaruh terhadap kecernaan BETN pada Domba Garut jantan.

2. Rasio silase campuran Indigofera $s p$. dan Rumput Gajah yang menghasilkan nilai kecernaan serat kasar tertinggi adalah silase campuran Indigofera $s p$. $20 \%$ dan Rumput Gajah 80\%.

\section{Saran}

Sebaiknya dilakukan uji coba penelitian tentang penggunaan Indigofera $s p$. dalam bentuk segar pada Domba untuk menambah referensi ilmiah.

Tabel 2. Nilai Kecernaan BETN Ransum Perlakuan

\begin{tabular}{|c|c|c|c|c|c|}
\hline \multirow{2}{*}{ Ulangan } & \multicolumn{5}{|c|}{ Perlakuan } \\
\hline & $\mathrm{T} 1$ & $\mathrm{~T} 2$ & T3 & $\mathrm{T} 4$ & T5 \\
\hline & & & $\%$. & & \\
\hline 1 & 43,56 & 57,55 & 71,58 & 50,28 & 59,67 \\
\hline 2 & 51,74 & 49,53 & 67,72 & 66,85 & 55,39 \\
\hline 3 & 52,24 & 70,19 & 54,94 & 58,61 & 58,33 \\
\hline 4 & 55,44 & 65,68 & 51,10 & 52,60 & 54,17 \\
\hline 5 & 70,69 & 64,11 & 62,03 & 47,69 & 39,17 \\
\hline Rataan & 54,73 & 61,41 & 61,47 & 55,21 & 53,35 \\
\hline
\end{tabular}




\section{Ucapan Terima Kasih}

Ucapan terima kasih disampaikan kepada Tim Penelitian yang di ketuai oleh Ir. Siti Nurachma, MS. yang merupakan dari Bagian Program Hibah Internal Unpad (HIU) yang telah memberikan kesempatan untuk bergabung dalam kegiatan.

\section{Daftar Pustaka}

Anggorodi, R. 1990. Ilmu Makanan Ternak Umum. Penerbit Gramedia. Jakarta. 46-51; 193-196.

Budiman, A., T. Dhalika., dan B. Ayuningsih. 2006. Uji Kecernaan Serat Kasar dan Bahan Ekstrak Tanpa Nitrogen (BETN) dalan Ransum Lengkap Berbasis Hijauan Daun Pucuk Tebu (Saccharum officinarum). Jurnal Ilmu Ternak Vol. 6(2): 132-135.

Firdaus. 2010. Pengaruh Formulasi Pakan Hijauan (Rumput Gajah, Kaliandra, dan Gamal) terhadap Pertumbuhan dan Bobot Karkas Domba. Jurnal Agripet Vol. 10(1): 42-45.

Ginting, P. S., B. R. Prawiradiputra, dan N. D. Purwantari. 2012. Indigofera sebagai
Pakan Ternak. IAARD Press. Jakarta. 59-75.

Parakkasi, A. 1999. Ilmu Nutrisi dan Makanan Ternak Ruminansia. UI Press. Jakarta. $23 ; 75$.

Sudirman., Suhubdy, S. D. Hasan., S. H. Dilaga., dan I. W. Karda. 2015. Kandungan Neutral Detergent Fibre (NDF) dan Acid Detergent Fibre (ADF) Bahan Pakan Lokal Ternak Sapi yang Dipelihara pada Kandang Kelompok. Jurnal Ilmu dan Teknologi Peternakan Indonesia Vol. 1(1): 66-70.

Tarigan, A. dan S. P. Ginting. 2011. Pengaruh Taraf Pemberian Indigofera sp. Terhadap Konsumsi dan Kecernaan Pakan Serta Pertambahan Bobot Hidup Kambing yang Diberi Jenis Rumput Brachiaria ruziziensis. Jurnal Ilmu Ternak Vol. 16(1): 25-32.

Tillman, A.D, H. Hartadi, S. Reksohadiprodjo, S. Prawirokusumo, dan S. Lebdosoekojo. 1991. Ilmu Makanan Ternak Dasar. Gadjah Mada University Press. Yokyakarta. 144; 181;

249-259. 